\title{
Heterogeneity of a Tree Species Community in an Alluvial Area of Santa Catarina, Brazil
}

\author{
Didiane Ana Gonçalves ${ }^{1}$, Ana Carolina da Silva ${ }^{1}$, Pedro Higuchi ${ }^{1}$, Aline Gross ${ }^{1}$, \\ Luiz Carlos Rodrigues Junior ${ }^{1}$, Felipe Fornara Walter ${ }^{1}$, Rodineli Loebens ${ }^{1}$, \\ Francieli de Fátima Missio ${ }^{1}$, Francieli Pscheidt ${ }^{1}$, Tiago de Souza Ferreira ${ }^{1}$, \\ Carla Carolina Chini Rech ${ }^{1}$, Angélica Dalla Rosa ${ }^{1}$, Fernando Buzzi Junior ${ }^{1}$, \\ Marco Antonio Bento ${ }^{1}$, Aline Pereira Cruz ${ }^{1}$ \\ ${ }^{1}$ Universidade do Estado de Santa Catarina - UDESC, Lages/SC, Brasil
}

\begin{abstract}
The aim of the present study was to characterize the floristic-structural heterogeneity of the tree species in an alluvial forest remnant considering three sectors: forest-river edge, forest interior and forest/non-forest matrix edge. Forty-eight plots of $200 \mathrm{~m}^{2}$ were allocated and all tree individuals with a diameter at breast height (dbh) equal to or greater than $5 \mathrm{~cm}$ were measured and identified. Data was analyzed by Shannon's diversity index, Pielou evenness and phytosociological descriptors. Plots were ordered through NMDS. Sixty-six species were sampled and Myrtaceae was found to be the richest family. Diversity and evenness reached 2.96 and 0.71 , respectively. Sebastiania commersoniana (Baill.) L.B.Sm. \& Downs presented the highest importance value (21.22\%). The NMDS showed that tree components are spatially partitioned according to sectors, therefore indicating floristic-structural heterogeneity.
\end{abstract}

Keywords: floodplain forest, phytosociology, Mixed Ombrophilous Forest. 


\section{INTRODUCTION}

The Mixed Ombrophilous Forest (MOF) is located in the Atlantic Forest, occurring in the Brazilian southern plateau in fragmented areas in the southeast region and neighboring countries (Paraguay and Argentina) (Roderjan et al., 2002). This formation is known for a notable presence of Brazilian pine tree (Araucaria angustifolia (Bertol.) Kuntze) in a diverse association with important species, such as erva-mate (Ilex paraguariensis A. St.-Hil.), canela-lageana (Ocotea pulchella (Nees) Mez), and pinheiro-bravo (Podocarpus lambertii Klotzch ex Endl.), amongst others (Roderjan et al., 2002). Their high economic value has led to their exploitation, resulting in the fragmentation of such phytophysiognomy (Sevegnani et al., 2012).

MOF has different sub-formations. The Alluvial MOF occupies the alluvial lands associated with water courses. The abundant presence of Sebastiania commersoniana (Baill.) L.B.Sm. \& Downs (IBGE, 2012), a species adapted to water stress (Kolb et al., 1998), stands out in this type of forest. Adaptation to environments that are subject to periodic flooding is necessary as the soil air (oxygen) is replaced by water, thus reducing the amount of oxygen available for plants and creating a hypoxic or anoxic environment (Lobo \& Joly, 2000).

Alluvial forests play an important ecological role in maintaining water resources and species conservation, but they are threatened by different anthropic activities as they are located in strategic development areas (Silva et al., 2012a). Actions that aim to conserve and recover remnants are therefore necessary, so it is important to know which are suitable species and to learn the floristic-structural heterogeneity of the environment. The goal of this study was to carry out the phytosociological survey of an Alluvial MOF remnant as well as to characterize its floristic-structural heterogeneity by considering three forest sectors (forest-river edge, forest interior and forest/non-forest matrix).

\section{MATERIAL AND METHODS}

The study was carried out in an alluvial forest fragment of approximately 63 ha located on the banks of the Caveiras River, Lages, "Planalto Sul Catarinense" region, SC, Brazil. It is located at latitude $27^{\circ} 50^{\prime} 47.95^{\prime}$ 'S and longitude $50^{\circ} 13^{\prime} 32.26^{\prime \prime} \mathrm{O}$, reaching an altitude of around $925 \mathrm{~m}$. According to Köppen's classification, it presents a Cfb type climate where both mild winters and summers prevail. Its mean annual rainfall is $1,479.48 \mathrm{~mm}$ evenly distributed throughout the year and its mean annual temperature is $16^{\circ} \mathrm{C}$ (Brasil, 1992). Gleysols and Cambisols are its main soil classes. There is relief variation with alluvial plains being flooded during intense rainfall while sloping areas, mostly located in the sector bordering the opposite side of the river (forest/non-forest matrix edge) present no flooding.

Forty-eight $200 \mathrm{~m}^{2}(10 \times 20 \mathrm{~m})$ permanent plots were allocated for the phytosociological survey, constituting a total sampled area of $9,600 \mathrm{~m}^{2}$. Plots were distributed in a stratified way in three sectors (strata) (16 plots per sector): forest-river edge (adjacent to the river), forest interior and forest/non-forest matrix edge (adjacent to the grassland) (Figure 1). Each individual tree with dbh (diameter at breast height, measured at $1.30 \mathrm{~m}$ from the soil) equal to or higher than $5.0 \mathrm{~cm}$ from each plot, were measured and identified. All multiple tree trunks from the field where the square root of the sum of the squares of the dbh values was equal to or higher than $5.0 \mathrm{~cm}$ were measured. Trees were identified by consulting the literature and experts. Species were classified according to the APG IV system (Angiosperm Phylogeny Group, 2016). The geographical coordinates of each plot were determined using GPS and the slope of the four sides of each plot was measured with a clinometer. Subsequently, the mean slope per plot was also calculated. Both the coordinate and slope means were used to draw a map of the area, with slopes being grouped into three classes (Figure 1).

Sampling sufficiency was determined through the species accumulation curve performed by the Vegan package (Oksanen et al., 2014) from the statistical programming language $\mathrm{R}$ ( $\mathrm{R}$ Development Core Team, 2014). Diversity was estimated by the Shannon-Wiener index $\left(\mathrm{H}^{\prime}\right)$ and the evenness by the Pielou index $(\mathrm{J})$ (Brower \& Zar, 1984). The values of absolute and relative density, absolute and relative frequency, absolute and relative dominance, and the importance value (IV) were used as phytosociological descriptors in agreement to Mueller-Dombois \& Ellenberg (1974). The multivariate Nonmetric Multidimensional Scaling (NMDS) (Minchin, 1987) with Bray-Curtis distance was used to order the plots to detect the floristic-structural heterogeneity of the fragment. All further analyses were performed using the R program ( $\mathrm{R}$ Development Core Team, 2014) through the Vegan library (Oksanen et al., 2014). 


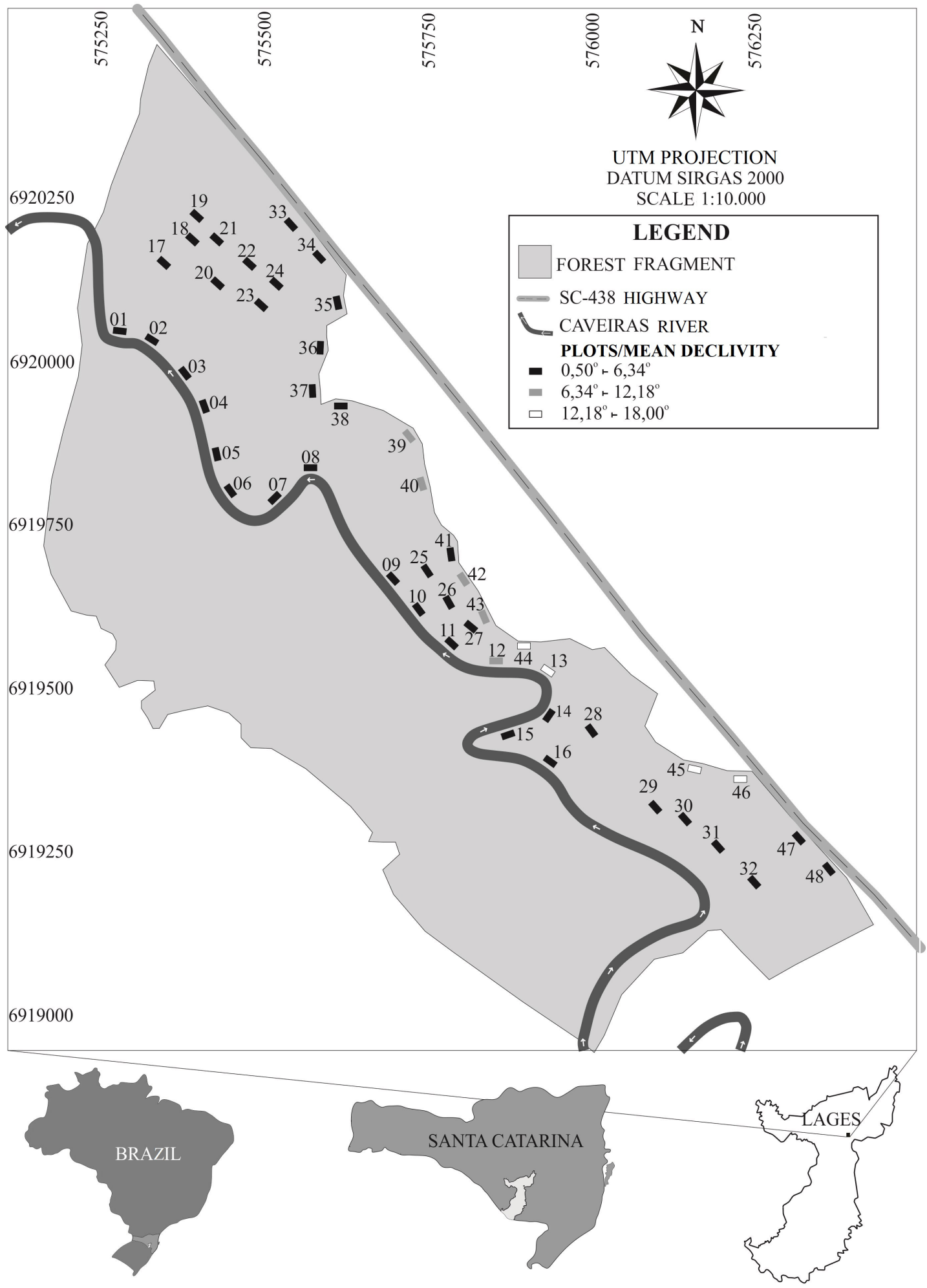

Figure 1. Location of the Alluvial MOF fragment, Lages, "Planalto Sul Catarinense" region, SC, Brazil. Plots from 1 to 16 belong to the forest-river edge sector; plots from 17 to 32 belong to the forest interior sector and plots from 33 to 48 belong to the forest/non-forest matrix sector. 


\section{RESULTS AND DISCUSSION}

A total of 1,462 individuals, belonging to 66 species (Table 1), 51 genera and 32 botanical families were sampled. Myrtaceae was the richest family (17 species), followed by Asteraceae, Aquifoliaceae, Euphorbiaceae, Fabaceae, Lauraceae, Salicaceae and Sapindaceae (three species each). The richest genus was Eugenia (four species), followed by Ilex and Myrcia (three species each). The high richness of the Myrtaceae family has also been found in other fragments of the Mixed Ombrophilous Forest of this region (e.g. Klauberg et al., 2010; Nascimento et al., 2011; Higuchi et al., 2012a; Higuchi et al., 2012b, 2013; Negrini et al., 2012; Silva et al., $2012 b$ ) and in alluvial forests of different states in southern and southeastern Brazil (e.g. Dias et al., 1998,

Table 1. Phytosociological descriptors of tree species sampled in an Alluvial MOF area, Lages, "Planalto Catarinense" region, SC, Brazil, ordered by importance value (IV, in \%).

\begin{tabular}{|c|c|c|c|c|c|c|c|}
\hline Species & AD & RD & ADo & RDo & AF & RF & IV \\
\hline Sebastiania commersoniana (Baill.) L.B.Sm. \& Downs & 404.17 & 26.54 & 8.56 & 27.98 & 87.50 & 9.13 & 21.22 \\
\hline Eugenia uniflora L. & 160.42 & 10.53 & 3.25 & 10.64 & 66.67 & 6.96 & 9.38 \\
\hline Blepharocalyx salicifolius (Kunth) O.Berg & 85.42 & 5.61 & 3.99 & 13.03 & 66.67 & 6.96 & 8.53 \\
\hline Allophylus edulis (A.St.-Hil., Cambess. \& A. Juss.) Radlk. & 141.67 & 9.30 & 1.41 & 4.61 & 72.92 & 7.61 & 7.17 \\
\hline Nectandra megapotamica (Spreng.) Mez & 83.33 & 5.47 & 1.72 & 5.62 & 45.83 & 4.78 & 5.29 \\
\hline Calyptranthes concinna DC. & 88.54 & 5.81 & 0.79 & 2.58 & 60.42 & 6.30 & 4.90 \\
\hline Casearia decandra Jacq. & 62.50 & 4.10 & 0.35 & 1.15 & 45.83 & 4.78 & 3.35 \\
\hline Campomanesia xanthocarpa O.Berg & 39.58 & 2.60 & 1.17 & 3.81 & 31.25 & 3.26 & 3.22 \\
\hline Prunus myrtifolia (L.) Urb. & 39.58 & 2.60 & 0.66 & 2.16 & 29.17 & 3.04 & 2.60 \\
\hline Araucaria angustifolia (Bertol.) Kuntze & 17.71 & 1.16 & 0.81 & 2.64 & 18.75 & 1.96 & 1.92 \\
\hline Banara tomentosa Clos & 23.96 & 1.57 & 0.39 & 1.26 & 27.08 & 2.83 & 1.89 \\
\hline Lithrea brasiliensis Marchand & 14.58 & 0.96 & 0.79 & 2.57 & 18.75 & 1.96 & 1.83 \\
\hline Annona rugulosa (Schltdl.) H.Rainer & 27.08 & 1.78 & 0.19 & 0.64 & 29.17 & 3.04 & 1.82 \\
\hline Ocotea pulchella (Nees) Mez & 15.63 & 1.03 & 0.81 & 2.64 & 16.67 & 1.74 & 1.80 \\
\hline Symplocos uniflora (Pohl) Benth. & 25.00 & 1.64 & 0.36 & 1.18 & 14.58 & 1.52 & 1.45 \\
\hline Myrrhinium atropurpureum Schott & 18.75 & 1.23 & 0.21 & 0.69 & 22.92 & 2.39 & 1.44 \\
\hline Jacaranda puberula Cham. & 22.92 & 1.50 & 0.44 & 1.44 & 8.33 & 0.87 & 1.27 \\
\hline Ilex theezans Mart. ex Reissek & 14.58 & 0.96 & 0.40 & 1.30 & 14.58 & 1.52 & 1.26 \\
\hline Matayba elaeagnoides Radlk. & 18.75 & 1.23 & 0.39 & 1.29 & 10.42 & 1.09 & 1.20 \\
\hline Myrcia palustris DC. & 21.88 & 1.44 & 0.13 & 0.43 & 14.58 & 1.52 & 1.13 \\
\hline Ocotea puberula (Rich.) Nees. & 9.38 & 0.62 & 0.36 & 1.19 & 12.50 & 1.30 & 1.04 \\
\hline Myrceugenia euosma (O.Berg) D. Legrand & 17.71 & 1.16 & 0.12 & 0.39 & 12.50 & 1.30 & 0.95 \\
\hline Podocarpus lambertii Klotzsch ex Endl. & 6.25 & 0.41 & 0.47 & 1.54 & 6.25 & 0.65 & 0.87 \\
\hline Zanthoxylum rhoifolium Lam. & 9.38 & 0.62 & 0.13 & 0.43 & 14.58 & 1.52 & 0.85 \\
\hline Sebastiania brasiliensis Spreng. & 14.58 & 0.96 & 0.15 & 0.50 & 8.33 & 0.87 & 0.78 \\
\hline Ilex dumosa Reissek & 7.29 & 0.48 & 0.22 & 0.71 & 10.42 & 1.09 & 0.76 \\
\hline Roupala montana Aubl. & 10.42 & 0.68 & 0.14 & 0.46 & 8.33 & 0.87 & 0.67 \\
\hline Strychnos brasiliensis (Spreng.) Mart. & 8.33 & 0.55 & 0.05 & 0.15 & 12.50 & 1.30 & 0.67 \\
\hline Erythrina cristagalli L. & 10.42 & 0.68 & 0.11 & 0.36 & 8.33 & 0.87 & 0.64 \\
\hline Campomanesia rhombea O.Berg & 5.21 & 0.34 & 0.15 & 0.48 & 10.42 & 1.09 & 0.64 \\
\hline Sapium glandulosum (L.) Morong & 3.13 & 0.21 & 0.27 & 0.88 & 6.25 & 0.65 & 0.58 \\
\hline Dasyphyllum brasiliense (Spreng.) Cabrera & 4.17 & 0.27 & 0.13 & 0.43 & 8.33 & 0.87 & 0.52 \\
\hline Xylosma ciliatifolia (Clos) Eichler & 5.21 & 0.34 & 0.08 & 0.26 & 8.33 & 0.87 & 0.49 \\
\hline Schinus terebinthifolius Raddi & 5.21 & 0.34 & 0.06 & 0.20 & 8.33 & 0.87 & 0.47 \\
\hline Dasyphyllum spinensis (Less.) & 4.17 & 0.27 & 0.20 & 0.67 & 4.17 & 0.43 & 0.46 \\
\hline Eugenia pluriflora DC. & 5.21 & 0.34 & 0.03 & 0.11 & 8.33 & 0.87 & 0.44 \\
\hline Dalbergia frutescens (Vell.) Britton & 5.21 & 0.34 & 0.03 & 0.10 & 8.33 & 0.87 & 0.44 \\
\hline Vernonanthura discolor (Spreng.) H.Rob. & 3.13 & 0.21 & 0.19 & 0.64 & 4.17 & 0.43 & 0.43 \\
\hline
\end{tabular}

$\mathrm{AD}=$ absolute density (ind./ha); $\mathrm{RD}=$ relative density $(\%) ; \mathrm{ADo}=$ absolute dominance $\left(\mathrm{m}^{2} / \mathrm{ha}\right) ; \mathrm{RDo}=$ relative dominance $(\%) ;$ $\mathrm{AF}=$ absolute frequency (\%); $\mathrm{RF}=$ relative frequency (\%); $\mathrm{IV}=$ importance value (\%). 
Table 1. Continued...

\begin{tabular}{|c|c|c|c|c|c|c|c|}
\hline Species & AD & RD & ADo & RDo & AF & RF & IV \\
\hline Lamanonia ternata Vell. & 5.21 & 0.34 & 0.06 & 0.21 & 6.25 & 0.65 & 0.40 \\
\hline Scutia buxifolia Reissek & 5.21 & 0.34 & 0.05 & 0.17 & 6.25 & 0.65 & 0.39 \\
\hline Drimys brasiliensis Miers & 5.21 & 0.34 & 0.04 & 0.13 & 6.25 & 0.65 & 0.38 \\
\hline Myrcia laruotteana Camb. & 5.21 & 0.34 & 0.03 & 0.09 & 6.25 & 0.65 & 0.36 \\
\hline Myrceugenia myrcioides (Cambess.) O. Berg & 4.17 & 0.27 & 0.02 & 0.08 & 6.25 & 0.65 & 0.33 \\
\hline Eugenia pyriformis Cambess. & 2.08 & 0.14 & 0.12 & 0.38 & 4.17 & 0.43 & 0.32 \\
\hline Myrcia guianensis (Aubl.) DC. & 2.08 & 0.14 & 0.10 & 0.32 & 4.17 & 0.43 & 0.30 \\
\hline Myrciaria delicatula (DC.) O.Berg & 3.13 & 0.21 & 0.04 & 0.15 & 4.17 & 0.43 & 0.26 \\
\hline Myrsine umbellata Mart. & 2.08 & 0.14 & 0.02 & 0.08 & 4.17 & 0.43 & 0.22 \\
\hline Ilex paraguariensis A. St.-Hil. & 2.08 & 0.14 & 0.02 & 0.06 & 4.17 & 0.43 & 0.21 \\
\hline Maytenus boaria Molina & 2.08 & 0.14 & 0.02 & 0.05 & 4.17 & 0.43 & 0.21 \\
\hline Duranta vestita Cham. & 2.08 & 0.14 & 0.01 & 0.03 & 4.17 & 0.43 & 0.20 \\
\hline Oreopanax fulvus Marchal & 3.13 & 0.21 & 0.05 & 0.18 & 2.08 & 0.22 & 0.20 \\
\hline Maytenus dasyclada Mart. & 2.08 & 0.14 & 0.01 & 0.02 & 4.17 & 0.43 & 0.20 \\
\hline Erythroxylum deciduum A.St.-Hil. & 1.04 & 0.07 & 0.07 & 0.23 & 2.08 & 0.22 & 0.17 \\
\hline Cupania vernalis Cambess. & 1.04 & 0.07 & 0.06 & 0.19 & 2.08 & 0.22 & 0.16 \\
\hline Escallonia bifida Link \& Otto & 2.08 & 0.14 & 0.03 & 0.10 & 2.08 & 0.22 & 0.15 \\
\hline Myrsine coriacea (Sw.) R.Br. & 2.08 & 0.14 & 0.01 & 0.03 & 2.08 & 0.22 & 0.13 \\
\hline Mimosa scabrella Benth. & 1.04 & 0.07 & 0.03 & 0.09 & 2.08 & 0.22 & 0.12 \\
\hline Solanum sanctaecatharinae Dunal & 1.04 & 0.07 & 0.02 & 0.06 & 2.08 & 0.22 & 0.12 \\
\hline Myrcianthes gigantea (D. Legrand) D. & 1.04 & 0.07 & 0.02 & 0.06 & 2.08 & 0.22 & 0.11 \\
\hline Clethra scabra Pers. & 1.04 & 0.07 & 0.01 & 0.04 & 2.08 & 0.22 & 0.11 \\
\hline Bastardiopsis densiflora (Hook. \& Arn.) Hassl. & 1.04 & 0.07 & 0.01 & 0.04 & 2.08 & 0.22 & 0.11 \\
\hline Ligustrum sinense Lour. & 1.04 & 0.07 & 0.01 & 0.03 & 2.08 & 0.22 & 0.11 \\
\hline Zanthoxylum kleinii (R.S.Cowan) & 1.04 & 0.07 & 0.01 & 0.02 & 2.08 & 0.22 & 0.10 \\
\hline Acca sellowiana (O.Berg) Burret & 1.04 & 0.07 & 0.01 & 0.02 & 2.08 & 0.22 & 0.10 \\
\hline Eugenia uruguayensis Cambess. & 1.04 & 0.07 & 0.01 & 0.02 & 2.08 & 0.22 & 0.10 \\
\hline Dicksonia sellowiana Hook. & 1.04 & 0.07 & 0.00 & 0.01 & 2.08 & 0.22 & 0.10 \\
\hline Total & 1522.9 & 100.0 & 30.6 & 100.0 & 958.3 & 100.0 & 100.0 \\
\hline
\end{tabular}

$\mathrm{AD}=$ absolute density (ind./ha); $\mathrm{RD}=$ relative density $(\%) ; \mathrm{ADo}=$ absolute dominance $\left(\mathrm{m}^{2} / \mathrm{ha}\right) ; \mathrm{RDo}=\mathrm{relative}$ dominance $(\%)$; $\mathrm{AF}=$ absolute frequency $(\%) ; \mathrm{RF}=$ relative frequency $(\%) ; \mathrm{IV}=$ importance value $(\%)$.

in PR; Botrel et al., 2002, in MG; Bianchini et al., 2003, in PR; Araujo et al., 2004, in RS, Barddal et al., 2004, in PR; Budke et al., 2004, in RS; Rolim et al., 2006, in ES; Budke et al., 2007, in RS; Budke et al., 2008, in RS; Silva et al., 2009, in MG). The species richness values observed represent the fragment being studied, since the species accumulation curve tended to stabilize (Figure 2). According to Kersten \& Galvão (2011), sufficiency is reached when the line tends towards stability and the addition of new species does not significantly alter the number of species - it is suggested that a $10 \%$ increase in the sample area results in an increase of up to $5 \%$ new species. Since richness has only increased $0.48 \%$ by adding the last plot, which corresponds to $2.08 \%$ of the sampled area, we concluded that sample sufficiency was therefore achieved.

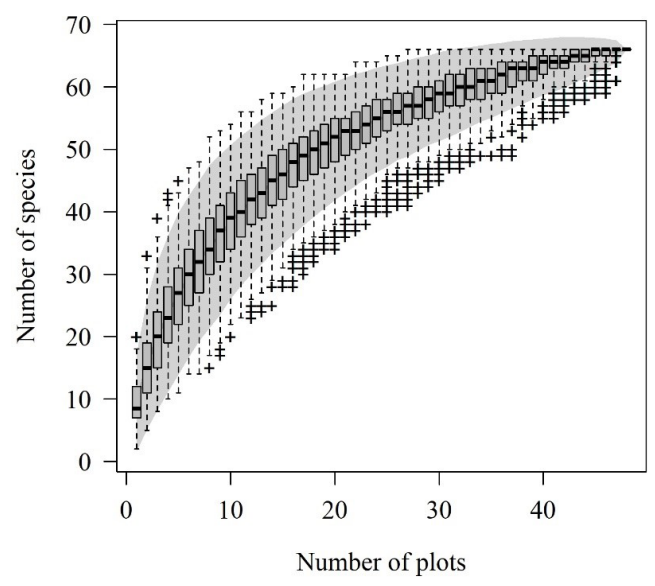

Figure 2. Accumulation curve of species sampled in an Alluvial MOF fragment, Lages, "Planalto Sul Catarinense" region, SC, Brazil. 
A Shannon diversity ( $\left.\mathrm{H}^{\prime}\right)$ index of 2.96 and a Pielou's evenness $(\mathrm{J})$ index of 0.71 were obtained. Studies in non-alluvial MOF of this region showed diversity and evenness values ranging from 2.79 and 0.70 in upper montane MOF (Higuchi et al., 2013) and 3.74 and 0.86 in montane MOF (Higuchi et al., 2012a), respectively. The low values observed in the upper montane forest are the result of a more restricted environment due to the intense cold found in the highest altitudes of this region. The limiting environment is also the reason why the diversity and evenness values are usually reduced in alluvial forests; in this case, the limitation is due to water excess. According to Junk (1993), flood stress and increased erosion and sedimentation rates reduce tree species diversity. Other studies in alluvial forests have also revealed low diversity values, such as Vilela et al. (2000), Budke et al. (2004) and Silva et al. (2009), who found $H^{\prime}$ values of $0.93,2.73$, and 2.36, respectively. A higher diversity value was probably observed because there are also slopes in this area (some plots from the forest/non-forest matrix edge), where non-common species have been found in flood areas, thereby increasing richness. In addition, a range of diversity values may be observed in response to the environmental heterogeneity of alluvial forests, which are found in different climates, soil conditions, vegetation matrices and disturbance histories, as well as factors related to flooding, such as the degree and time of flooding (Silva et al., 2012a).

Low diversity values are also influenced by high ecological dominance in addition to low species richness, which has been confirmed by a Pielou index value lower than those found in other non-alluvial forests of this region. High ecological dominance is common in flood environments (Silva et al., 2012a). Budke et al. (2004) reported a Pielou index of 0.69 in an alluvial environment whereas Marques et al. (2003) found a value of 0.71 in a swamp forest.

Myrtaceae (444), Euphorbiaceae (405), Sapindaceae (155), Lauraceae (104) and Salicaceae (88) showed the greatest representativeness in number of individuals in the community. Barddal et al. (2004), when studying a seasonally flooded area of an alluvial forest located in Araucaria, PR, Brazil, also found Euphorbiaceae and Myrtaceae to be the most abundant families, indicating that such a pattern may be common in alluvial MOFs.
Sebastiania commersoniana obtained the highest relative importance in the fragment studied, with an IV of $21.22 \%$. Such a high IV is the result of the species' high density $(\mathrm{RD}=26.54 \%)$, dominance $(\mathrm{RDo}=27.50 \%)$ and frequency (it was observed in $87.5 \%$ of the plots) in this area. According to Silva et al. (2007), species such as Sebastiania commersoniana may be found in flood-free environments but are more abundant in alluvial forests, where interspecific competition is lower thanks to water selection. The occurrence of this species with a high IV in alluvial forests, especially in southern and southeastern Brazil, is therefore common. Barddal et al. (2004) and Carvalho et al. (2016) have respectively found an IV (transformed into percentage) of $48.2 \%$ and $67.9 \%$ in PR, Brazil; and Silva et al. (2009) found an IV of $28.36 \%$ in MG, Brazil.

Eugenia uniflora presented the second highest IV (9.38\%), mainly due to its high density ( $\mathrm{RD}=10.53 \%)$. According to Rotman (1995), this species inhabits different vegetation formations, being common in humid soils. Blepharocalyx salicifolius (Kunth) O.Berg, presented lower density $(\mathrm{RD}=5.61 \%)$ than Allophylus edulis ( $\mathrm{RD}=9.30 \%)$, but higher IV (the third highest value: $8.53 \%$ ) due to its significant dominance (13.03\%), thus indicating larger individuals. The three species with the highest IV corresponded to $40 \%$ of the total IV of the area therefore demonstrating their dominance.

The NMDS ordering presented a $17.36 \%$ stress value, thereby proving acceptable for interpretation $(<20 \%)$. This showed that the tree component is spatially partitioned according to the sectors (forest-river edge, forest interior and forest/non-forest matrix), indicating heterogeneity in the community's organization (Figure 3). NMDS axis 1 has indicated the highest floristic-structural segregation in the forest/non-forest matrix sector. This sector also showed the highest plot dispersion, therefore indicating high internal variation, which means higher beta diversity. The highest slope variation at the forest/non-forest matrix edge (Figure 1) suggests a highly heterogeneous environment, which may have contributed to the results. The forest-river edge and forest interior sectors presented greater similarity to each other, with partial overlapping of plots. However, the forest interior sector showed greater plot dispersion in axis 2 , while plots adjacent to the river were grouped more cohesively, therefore indicating a higher internal homogeneity along the forest-river edge. It is therefore possible to infer the 


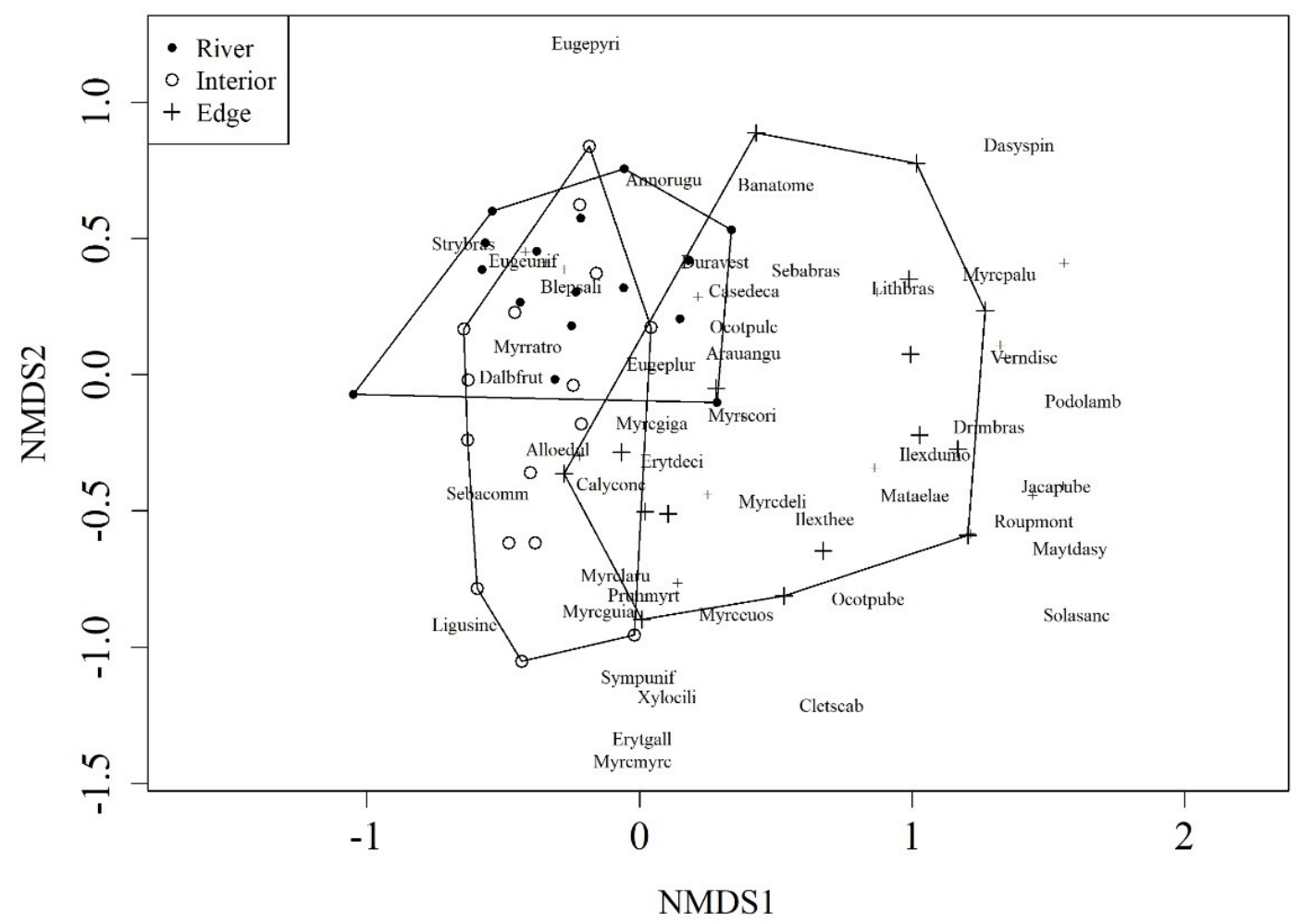

Figure 3. Plots and species ordination through NMDS (Nonmetric Multidimensional Scaling) in an Alluvial MOF fragment, Lages, "Planalto Sul Catarinense" region, SC, Brazil.

existence of a more selective environment adjacent to the river, which may be due to the sector's higher susceptibility to flood events.

Species like Strychnos brasiliensis (Spreng.) Mart. and Blepharocalyx salicifolius have shown a greater association with the forest-river edge and forest interior sectors (NMDS overlapping area). Ribeiro et al. (2007) also classified Blepharocalyx salicifolius as a species with a preference for moist soils. Several species were exclusive to the forest/non-forest matrix edge, such as Lithrea brasiliensis Marchand, Vernonanthura discolor (Spreng.) H.Rob., Jacaranda puberula Cham., Myrceugenia euosma (O.Berg) D. Legrand, Myrciaria delicatula (DC.) O.Berg, Roupala montana Aubl., Drimys brasiliensis Miers, etc. These species are probably exclusive to this sector for two main reasons: i) because they are early successional species (as pioneers or light-demanding climax species) since the forest/non-forest matrix edge receives more light; ii) because they are water stress intolerant species, since less flooding is expected in the sector farther away to the river - with the environment being well drained in the slope area. Such species have been observed in former studies in non-alluvial MOF areas, such as Nascimento et al. (2001), Rondon et al. (2002), Klauberg et al. (2010), Higuchi et al. (2012a), and Silva et al. (2012b). The species with the highest importance value in the community - Sebastiania commersoniana, Eugenia uniflora and Blepharocalyx salicifolius-occurred throughout all sectors, proving to be habitat generalists.

\section{CONCLUSIONS}

The tree community has shown a floristic-structural composition similar to that of other alluvial forests already studied in southern and southeastern Brazil, with a high richness of the Myrtaceae family, but with a low total richness, which along with the high ecological dominance resulted in low diversity. The high dominance reflected the significant participation of three main species - Sebastiania commersoniana, Eugenia uniflora and Blepharocalyx salicifolius. Sebastiania commersoniana is mentioned in the literature on alluvial forests from southern and southeastern Brazil as one of the most common species in such environments. 
The tree community organization presented a floristic-structural variation associated with the sectors considered for the study, suggesting the influence of environmental gradients that may be related to the river's hydrological cycles, soils, topography and edge effect. A group of species better adapted to periodic flooding is observed closer to the river and in the forest interior, while areas with steeper topography and a group of exclusive species, including some early successional ones, are observed in the sector bordering the opposite side of the river. Future studies focusing on environmental characterization of the area, natural regeneration and long term monitoring of the tree component are necessary to better understand the forest fragment's ecology.

\section{ACKNOWLEDGEMENTS}

We would like to thank the CNPq for providing a research productivity grant to the second and third authors, and the FAPESC for the financial support granted through the PAP/UDESC notice.

\section{SUBMISSION STATUS}

Received: 16 may, 2014

Accepted: 27 oct., 2017

\section{CORRESPONDENCE TO}

\section{Pedro Higuchi}

Departamento de Engenharia Florestal, Universidade do Estado de Santa Catarina UDESC, Av. Luiz de Camões, 2090, CEP 88520-000, Lages, SC, Brasil

e-mail: higuchip@gmail.com

\section{FINANCIAL SUPPORT}

\section{CNPq, FAPESC, PAP/UDESC.}

\section{REFERENCES}

Angiosperm Phylogeny Group. An update of the Angiosperm Phylogeny Group classification for the orders and families of flowering plants: APG IV. Botanical Journal of the Linnean Society 2016; 181(1): 1-20. http://dx.doi. org/10.1111/boj.12385.
Araujo MM, Longhi SJ, Brena DA, Barros PLC, Franco S. Análise de agrupamento da vegetação de um fragmento de Floresta Estacional Decidual Aluvial, Cachoeira do Sul, RS, Brasil. Ciência Florestal 2004; 14(1): 133-147. http://dx.doi.org/10.5902/198050981789.

Barddal ML, Roderjan CV, Galvão F, Curcio GR. Caracterização florística e fitossociológica de um trecho sazonalmente inundável de floresta aluvial, em Araucária, PR. Ciência Florestal 2004; 14(2): 37-50. http://dx.doi. org/10.5902/198050981805.

Bianchini E, Popolo RS, Dias MC, Pimenta JA. Diversidade e estrutura de espécies arbóreas em área alagável do município de Londrina, sul do Brasil. Acta Botanica Brasílica 2003; 17(3): 405-419. http://dx.doi.org/10.1590/ S0102-33062003000300008.

Botrel R, Oliveira AT Fo, Rodrigues LA, Curi N. Influência do solo e topografia sobre as variações da composição florística e estrutura da comunidade arbóreo-arbustiva de uma floresta estacional semidecidual em Ingaí, MG. Revista Brasileira de Botanica. Brazilian Journal of Botany 2002; 25(2): 195-213. http://dx.doi.org/10.1590/S010084042002000200008 .

Brasil. Ministério da Agricultura e Reforma Agrária - MARA. Normas climatológicas 1961-1990. Brasília: MARA; 1992.

Brower JE, Zar JH. Field and laboratory methods for general ecology. Duduque: W.M.C. Brow Publishers; 1984.

Budke JC, Giehl ELH, Athayde EA, Eisinger SM, Záchia RA. Florística e fitossociologia do componente arbóreo de uma floresta ribeirinha, Arroio Passo das Tropas, Santa Maria, RS, Brasil. Acta Botanica Brasílica 2004; 18(3): 581 589. http://dx.doi.org/10.1590/S0102-33062004000300016.

Budke JC, Jarenkow JA, Oliveira AT Fo. Relationships between tree component structure, topography and soils of a riverside forest, Rio Botucaraí, Southern Brazil. Plant Ecology 2007; 189(2): 187-200. http://dx.doi.org/10.1007/ s11258-006-9174-8.

Budke JC, Jarenkow JA, Oliveira AT Fo. Tree community features of two stands of riverine forest under different flooding regimes in Southern Brazil. Flora 2008; 203(2): 162-174. http://dx.doi.org/10.1016/j.flora.2007.03.001.

Carvalho J, Galvão F, Rios RC, Velazco SJE. Monospecific dominance in an Alluvial Mixed Ombrophyllous Forest in Southern Brazil. Australian Journal of Basic and Applied Sciences 2016; 10(10): 38-44.

Dias MC, Vieira AOS, Nakajima JN, Pimenta JA, Lobo PC. Composição florística e fitossociologia do componente arbóreo das florestas ciliares do rio Iapó, na bacia do rio Tibagi, Tibagi, PR. Revista Brasileira de Botanica. Brazilian Journal of Botany 1998; 21(2): 183-195. http://dx.doi. org/10.1590/S0100-84041998000200011.

Higuchi P, Silva AC, Almeida JA, Bortoluzzi RLC, Mantovani A, Ferreira TS et al. Florística e estrutura do componente 
arbóreo e análise ambiental de um fragmento de Floresta Ombrófila Mista Alto-Montana no município de Painel, SC. Ciência Florestal 2013; 23(1): 153-164. http://dx.doi. org/10.5902/198050988449.

Higuchi P, Silva AC, Ferreira TS, Souza ST, Gomes JP, Silva KM et al. Influência de variáveis ambientais sobre o padrão estrutural e florístico do componente arbóreo, em um fragmento de Floresta Ombrófila Mista Montana em Lages, SC. Ciência Florestal 2012a; 22(1): 79-90. http:// dx.doi.org/10.5902/198050985081.

Higuchi P, Silva AC, Ferreira TS, Souza ST, Gomes JP, Silva $\mathrm{KM}$ et al. Floristic composition and phytogeography of the tree component of Araucaria Forest fragments in southern Brazil. Brazilian Journal of Botany 2012b; 35(2): 145-157. http://dx.doi.org/10.1590/S1806-99592012000200004.

Instituto Brasileiro de Geografia e Estatística - IBGE. Manual técnico da vegetação brasileira. Rio de Janeiro: IBGE; 2012.

Junk WJ. Wetlands of Tropical South America. In: Hejný S, Dykyjová D, editors. Wetlands of the world I: inventory, ecology and management. Dordrecht: Dr. W. Junk Publ.; 1993. http://dx.doi.org/10.1007/978-94-015-8212-4_14.

Kersten RA, Galvão F. Suficiência amostral em inventários florísticos e fitossociológicos. In: Felfili JM, Eisenlohr PV, Melo MMRF, Andrade LA, Meira JAA No, editores. Fitossociologia no Brasil: métodos e estudos de casos. Viçosa: Editora UFV; 2011.

Klauberg C, Paludo GF, Bortoluzzi RC, Mantovani A. Florística e estrutura de um fragmento de Floresta Ombrófila Mista no Planalto Catarinense. Biotemas 2010; 23(1): 35-47.

Kolb RM, Medri ME, Bianchini E, Pimenta JA, Giloni PC, Correa GT. Anatomia ecológica de Sebastiania commersoniana (Baillon) Smith \& Downs (Euphorbiaceae) submetida ao alagamento. Revista Brasileira de Botanica. Brazilian Journal of Botany 1998; 21(3): 305-312. http:// dx.doi.org/10.1590/S0100-84041998000300010.

Lobo PC, Joly CA. Aspectos ecofisiológicos da vegetação de mata ciliar do Sudeste do Brasil. In: Rodrigues RR, Leitão HF Fo, editores. Matas ciliares: conservação e recuperação. São Paulo: Editora da Universidade de São Paulo; 2000.

Marques MCM, Silva SM, Salino A. Florística e estrutura do componente arbustivo-arbóreo de uma floresta higrófila da bacia do rio Jacaré-Pepira, SP, Brasil. Acta Botanica Brasílica 2003; 17(4): 495-506. http://dx.doi.org/10.1590/ S0102-33062003000400002.

Minchin P. An evaluation of the relative robustness of techniques for ecological ordination. Plant Ecology 1987; 69(1): 89-107. http://dx.doi.org/10.1007/BF00038690.

Mueller-Dombois D, Ellenberg H. Aims and methods of vegetation ecology. New York: Wiley; 1974.

Nascimento ART, Longhi SJ, Brena DA. Estrutura e padrões de distribuição espacial de espécies árboreas em uma amostra de floresta Ombrófila Mista em Nova Prata, RS. Ciência Florestal 2001; 11(1): 105-119. http:// dx.doi.org/10.5902/19805098499.

Nascimento ART, Ramos PHX, Dalmaso CA. Estrutura e classificação de um remanescente de floresta ripária no município de Lages, SC. Ciência Florestal 2011; 21(2): 209-218. http://dx.doi.org/10.5902/198050983224.

Negrini M, Aguiar MD, Vieira CT, Silva AC, Higuchi P. Dispersão, distribuição espacial e estratificação vertical da comunidade arbórea em um fragmento florestal no Planalto Catarinense. Revista Árvore 2012; 36(5): 919-930. http://dx.doi.org/10.1590/S0100-67622012000500014.

Oksanen J, Blanchet FG, Kindt R, Legendre P, Minchin PR, O'Hara RB et al. Vegan: community ecology package [online]. 2014 [cited 2014 Jan 15]. Available from: http:// CRAN.R-project.org/package=vegan

$\mathrm{R}$ Development Core Team. R: a language and environment for statistical computing [online]. 2014 [cited 2014 Jan 15]. Available from: http://www.R-project.org

Ribeiro SB, Longhi SJ, Brena DA, Nascimento ART. Diversidade e classificação da comunidade arbórea da Floresta Ombrófila Mista da FLONA de São Francisco de Paula, RS. Ciência Florestal 2007; 17(2): 101-108. http:// dx.doi.org/10.5902/198050981941.

Roderjan CV, Galvão F, Kuniyoshi YS, Hatschbach GG. As unidades fitogeográficas do estado do Paraná. Ciência \& Ambiente 2002; 24: 75-92.

Rolim SG, Ivanauskas NM, Rodrigues RR, Nascimento MT, Gomes JML, Folli DA et al. Composição Florística do estrato arbóreo da Floresta Estacional Semidecidual na Planície Aluvial do rio Doce, Linhares, ES, Brasil. Acta Botanica Brasílica 2006; 20(3): 549-561. http://dx.doi. org/10.1590/S0102-33062006000300005.

Rondon RM No, Watzlawick LF, Caldeira MVW, Schoeninger ER. Análise florística e estrutural de um fragmento de Floresta Ombrófila Mista Montana, situado em Criúva, RS - Brasil. Ciência Florestal 2002; 12(1): 29-37. http:// dx.doi.org/10.5902/198050981698.

Rotman AD. Las especies argentinas del género Eugenia (Myrtaceae). Boletín de la Sociedad Argentina de Botánica 1995; 31(1-2): 69-93.

Sevegnani L, Silva TC, Gasper AL, Meyer L, Verdi M. Flora arbórea e o impacto humano nos fragmentos florestais na bacia do Rio Pelotas, Santa Catarina, Brasil. Revista de Estudos Ambientais 2012; 14(1): 60-73.

Silva AC, Higuchi P, van den Berg E, Nunes MH, Carvalho DA. Florestas Inundáveis: ecologia, florística e adaptações das espécies. Lavras: Editora da UFLA; 2012a.

Silva AC, Higuchi P, Aguiar MD, Negrini M, Fert J No, Hess AF. Relações florísticas e fitossociologia de uma Floresta Ombrófila Mista Montana Secundária em Lages, Santa Catarina. Ciência Florestal 2012b; 22(1): 193-206. http://dx.doi.org/10.5902/198050985091. 
Silva AC, van den Berg E, Higuchi P, Oliveira AT Fo, Marques JGSEM, Appolinário V et al. Florística e estrutura da comunidade arbórea em fragmentos de floresta aluvial em São Sebastião da Bela Vista, Minas Gerais. Revista Brasileira de Botanica. Brazilian Journal of Botany 2009; 32(2): 283297. http://dx.doi.org/10.1590/S0100-84042009000200008.

Silva AC, van den Berg E, Higuchi P, Oliveira AT Fo. Comparação florística de florestas inundáveis das regiões
Sudeste e Sul do Brasil. Revista Brasileira de Botanica. Brazilian Journal of Botany 2007; 30(2): 257-269. http:// dx.doi.org/10.1590/S0100-84042007000200010.

Vilela EA, Oliveira AT Fo, Carvalho DA, Guilherme FAG, Appolinário V. Caracterização estrutural de floresta ripária do Alto Rio Grande, em Madre de Deus de Minas, MG. Cerne 2000; 6(2): 41-54. 